\title{
In memoriam Prof. dr. Székely Lajos (1923-2017)
}

Beküldve: 2017. 10. 27.

doi: 10.24365/ef.v58i4.199

Hosszú, türelemmel viselt betegség után 94 éves korában csendesen elhunyt Prof. dr. Székely Lajos az egészségnevelés ikonikus alakja. Nevéhez füződik az egészségnevelés diszciplínájának elméleti és módszertani megalapozása.

Tanult teológiát, pszichológiát, szociológiát, jogot, oklevelet szerzett klinikai és pedagógiai szakpszichológiából, múvelte a klasszika-filológiát mint latin-, görög-, filozófia szakos tanár. Közel 70 évet töltött az egészségügy, az egészségnevelés szolgálatában. Az országos hírú professzor számos tudományos és ismeretterjesztő munkával gazdagította és oktatta az intézeti, majd főiskolai és végül egyetemi végzettséget adó mentálhigiéniai és egészségnevelő szakembereket, az egészségügy szerteágazó területein dolgozókat. Alapított, majd vezetett tanszéket, főiskolát, elnökölt nemzetközi bizottságokat, és nagyon sokat tanított itthon és külföldön egyaránt.

Munkáját az Egészségügyi Felvilágosítási Központ (EFK) Módszertani Osztályvezetőjeként kezdte, majd a Fővárosi KÖJÁL-ban irányította az egészségügyi felvilágosítást. Az egészségnevelés társadalmasításában nagy szerepet játszott munkássága, amelynek eredményeként elsőként a fővárosban, a Fővárosi Tanács háttérintézményeként múködő Fővárosi Egészségnevelési Központban (FEK) felügyelte és koordinálta a kerületi Tanácsoknál dolgozó egészségnevelők hálózatát.

Az egészségnevelés történetében nagy lépés volt, amikor 1975-ben munkásságával megalapozta az egészségnevelők intézményes főiskolai képzését az Orvostovábbképző Intézet Egészségügyi Főiskolai Karának Pedagógiai Intézetében, ahol fóiskolai tanárként tevékenykedett tovább. A ma is dolgozó egészségnevelők, védőnők, ápolónők jelentős része az ő tanítványai voltak. Neve megkerülhetetlen az egészségnevelés diszciplínájában, számos tudományos publikáció, szakkönyv, főiskolai jegyzet szerzője. Az Egészségnevelés c. folyóirat első szerkesztője volt.

A civil szférában is úttörő munkát végzett; alapítója volt az egészségnevelés területén dolgozókat összefogó Pápai Páriz Egészségnevelési Országos Egyesületnek.

Kiépítette az egészségnevelés iránt elkötelezett óvodapedagógusokat összefogó Egészségesebb Óvodák Nemzeti Hálózatát.

Munkásságának elismeréseként megkapta a Magyar Köztársaság Érdemrend arany fokozatát.

Emlékét megőrizzük: tanítványai, munkatársai, tisztelői. 